JURNAL NOMOSLECA

Volume 4 Nomor 1, April 2018

\title{
KOMUNIKASI VERBAL FOTOGRAFER DAN MODEL DALAM PROSES PEMOTRETAN
}

(Studi Interaksi Simbolik tentang Komunikasi Verbal dalam Interaksi Fotografer dan Model)

\author{
Wiki Angga Wiksana
}

Fakultas Ilmu Komunikasi, Universitas Islam Bandung wikianggawiksana@gmail.com

\begin{abstract}
Photographers can not be separated from social interaction or commonly called human relations, both in communicating with photo models, assistants, teams, and the surrounding environment. The most common area of photography among human interactions is model photography, because in this field the object of the photograph is human. In this study, there will be at least two people who interact, ie between the photographer and his model. This study aims to reveal the meaning of verbal interaction of photographers and models in the process of making photographs. The research method used is the interpretive approach study is a method that aims to interpret the case or subject studied. In this case, the data collection technique is done by in-depth interview, observation, and documentation study. The data validity test is triangulation technique, discussion with colleague, and member check. The result of this interpretive approach is the verbal interaction of photographers and photo models in the process of making the photographs vary, depending on the photographer and the model determining the role. Verbal interaction of photographers and models will be harmonious, harmonious, and balanced in accordance with ethical and moral values, if both parties respect each other's profession and primarily still uphold the ethical elements in the profession.
\end{abstract}

Keywords: Verbal Communication, Photographer, Model, Photo Shoot

\begin{abstract}
Abstrak
Fotografer tidak bisa lepas dari interaksi sosial atau biasa disebut human relation, baik dalam berkomunikasi dengan foto model, asisten, tim, dan lingkungan sekitarnya. Bidang fotografi yang paling sering terjadi interaksi di antara manusia adalah fotografi model, karena pada bidang ini objek fotonya adalah manusia. Dalam penelitian ini, akan terdapat minimal dua orang yang berinteraksi, yaitu antara fotografer dan modelnya. Penelitian ini bertujuan mengungkapkan makna interaksi verbal fotografer dan model dalam proses pembuatan karya foto. Metode penelitian yang digunakan adalah studi pendekatan interpretatif yaitu suatu metode yang bertujuan untuk memaknai kasus atau subjek yang diteliti. Dalam hal ini, teknik pengumpulan data tersebut dilakukan dengan wawancara mendalam, pengamatan, dan studi dokumentasi. Adapun uji keabsahan data yang dilakukan adalah teknik trianggulasi, diskusi dengan teman sejawat, dan member check. Hasil penelitian pendekatan interpretatif ini adalah interaksi verbal fotografer dan foto model dalam proses pembuatan karya foto terjadi secara bervariasi, bergantung dari fotografer dan model menentukan perannya. Interaksi verbal fotografer dan model akan berjalan harmonis, selaras, dan seimbang sesuai dengan nilai etika dan moral, jika kedua pihak tersebut saling menghargai profesi masing-masing dan utamanya tetap menjunjung tinggi unsur etika dalam berprofesi.
\end{abstract}

Kata Kunci: Komunikasi Verbal, Fotografer, Model, Pemotretan 


\section{PENDAHULUAN}

Seorang fotografer tentunya akan berkomunikasi dengan para model. Dalam hal ini, mereka akan membuat suasana lebih nyaman.Saat berinteraksi dengan mereka, seorang fotografer bisa memperhatikan bahasa tubuh mereka, sehingga dapat lebih mudah memahami ide sudut pandang dan pose yang diinginkan. Hasilnya adalah foto yang sesuai dengan konsep yang diinginkan fotografer. Bidang fotografi yang paling sering terjadi interaksi diantara manusia adalah fotografi model, karena pada bidang ini objek fotonya adalah manusia. Dalam hal ini, akan terdapat minimal dua orang yang berinteraksi, yaitu antara fotografer dan modelnya.

Dengan berkomunikasi dan berusaha untuk saling mengenal dan memahami, semua yang terlibat dalam pemotretan akan menjadi nyaman, sehingga fotografer pun bisa mengambil foto sesuai dengan apa yang diinginkan. Ada yang beranggapan bahwa untuk foto manusia, seorang fotografer lebih menyukai memotret sendiri daripada foto bersama kelompok fotografer lainnya, karena dengan begitu sang fotografer tidak akan terganggu oleh fotografer lainnya dan juga mungkin asisten-asistennya, juga dengan kerumitan peralatan fotografi. Dengan memotret sendiri, interaksi dengan modelnya akan lebih intensif sehingga dapat menghasilkan hasil karya foto yang lebih baik.

Fotografi memang sebuah hobi yang menyenangkan. Fotografer mengambil sebuah objek yang menarik dan hasilnya sesuai dengan apa yang ia harapkan, itulah yang membuat fotografer terpuaskan. Tetapi jangan mengira menjadi seorang fotografer handal dan profesional itu adalah hal yang mudah. Banyak yang harus diperhatikan saat sebelum pengambilan gambar, saat pengambilan gambar, dan ada banyak yang harus dilakukan setelah pengambilan gambar.
Mudahnya penggunaan kamera saat ini memungkinkan siapa saja dapat menjadi seorang fotografer. Saat fotografi masih menggunakan film seluloid, tidak semua orang dapat menggunakan kamera, diperlukannya skill dan kemampuan khusus untuk dapat menggunakan kamera. Tidak sembarang orang dapat menjadi seorang fotografer, hanya mereka yang telah menempuh pendidikan fotografi baik formal maupun nonformal yang dapat menjadi seorang fotografer. Kemajuan teknologi dibidang fotografi dapat membuat seseorang melompati proses belajar fotografi untuk menjadi seorang fotografer, dengan bermodal peralatan fotografi yang canggih seseorang tersebut sudah dapat membuat sebuat foto dan menyebut dirinya seorang fotografer.

Dari berbagai objek foto, objek foto yang paling populer adalah manusia. Beragam genre fotografi yang menempatkan manusia sebagai modelnya, mulai dari manusia dengan kegiatannya yang biasa disebut human interest, manusia dan apa yang dikenakannya atau fashion foto, sampai kepada sebuah kondisi pemotretan dimana manusia yang menjadi objek utamanya seperti pada foto model, glamour dan juga portrait.

Pertumbuhan fotografer yang menyukai objek fotonya manusia, atau yang lebih spesifik foto dengan objeknya seorang model tumbuh sangat pesat, hal ini dapat di cermati dari banyaknya partisipan fotografer dalam sesi hunting foto model, terkadang penyelenggara hunting foto model terpaksa harus membatasi jumlah peserta hunting karena rasio perbandingan fotografer dan model sangat jauh tidak seimbang.

Dalam penelitian ini, peneliti mengambil studi interaksi simbolik fotografer dan model dalam sesi pemotretan, baik komunikasi secara verbal maupun komunikasi secara nonverbal. Saat objek foto adalah seorang manusia, maka mutlak adanya sebuah interaksi didalamnya, karena untuk mendapatkan sebuah karya foto, fotografer selalu 
menyampaikan ide dan pemikirannya dalam konsep fotografi untuk direalisasikan model fotonya sehingga terciptanya sebuah karya foto yang diinginkan fotografer. Komunikasi yang baik antara fotografer dan model dalam membuat sebuah karya foto sangatlah penting guna tercapainya tujuan dari sesi pemotretan tersebut.

Komunikasi yang peneliti maksud dalam hal ini adalah cara interaksi fotografer dan model. Pada saat sekarang ini, dunia fotografi sangat diminati oleh semua orang yang ada diseluruh penjuru dunia ini. Baik sekedar hoby, maupun yang sudah menjadi profesi. Ada fotografer pemula dan yang sudah sangat ahli. Dengan memiliki kemampuan komunikasi yang baik, fotografer tentunya diuntungkan dengan mendapatkan foto yang sesuai dengan konsep fotografinya dan tidak mengganggu orang-orang disekitarnya dan mereka punakan lebih senang membantu dalam proses pemotretan tersebut.

Sebuah fakta yang cukup mengejutkan dibalik hasil harya foto model dan anggapan harmonisnya hubungan fotografer dan modelnya:

Sebuah survey yang dilakukan The Model Alliance pada awal tahun 2012. Model Alliance mengirimkan sebuah survey via online kepada 241 model, dan hanya 85 dari mereka yang merespon.Tapi tentunya hal tersebut tetap saja berarti. Banyak model, terutama di usia muda mengalami gangguan makan serta depresi. $68 \%$ dari model menderita depresi dan gelisah berlebih, sedangkan $50 \%$ mengaku menggunakan kokain (sejenis narkoba) saat bekerja. Masih ada lagi, 30\% dari mereka merasa disentuh secara tidak pantas (berlebih-pelecehan) dalam pemotretan, kemudian $28 \%$ mengatakan kalau mereka dipaksa berhubungan seksual oleh seseorang di tempat kerja. Ini menjadi hal yang sangat memprihatinkan karena kebanyakan dari mereka masih di bawah usia 18 tahun.

(http://www.cetitamu.com/cerita-gayahidup/Fashion/Artikel/Model-Alliance).
Banyak dari para model yang mengalami pelecehan seksual oleh fotografernya dan merasa tidak bisa mengatakannya pada agensi atau siapapun, karena meraka mungkin tidak mengerti bagaimana seharusnya yang terjadi dalam sebuah sesi pemotretan dan menganggap perlakuan fotografer terhadap dirinya adalah bagian dari profesionalisme seorang model yang dengan pasrah menerima apapun perlakuan fotografer terhadap dirinya.

Dalam penelitian ini, peneliti tertarik untuk meneliti secara mendalam tentang komunikasi fotografer foto model dalam proses pembuatan karya foto. Penelitiakan melakukan penelitian ini dengan pendekatan kualitatif dan menggunakan studi interaksi simbolik, yaitu pemaknaan tentang interaksi fotografer dengan foto modelnya. Dalam hal ini, penelitiakan menggunakan informan penelitian yaitu beberapa fotografer dan model.

Adapun alasan yang menguatkan peneliti melakukan penelitian karena pernyataan dari salah seorang model bernama Dewi Hasari yang merasa dilecehkan oleh sebagian fotografer yang tidak memiliki etika komunikasi.

"Ya, sebenernya aku ngerasa risih kalau pas lagi pemotretan diarahin sambil dipegang-pegang sama beberapa fotografer.Tapi aku suka ga bisa apaapa juga karena alasan profesionalisme, jadi diarahkan sesuai dengan petunjuk dari fotografernya.Ya, mau gimana lagi, aku juga udah mencintai dunia modeling, meskipun gak suka dengan para fotografer yang suka curi-curi kesempatan sambil megang-megang aku."

Jika kita cermati, para fotografer hanya berkarya dengan mengabaikan unsur etika. Sebagaimana telah disinggung di atas, bahwa inilah realita yang terjadi saat ini. Oleh karena itu, peneliti tertarik untuk melakukan penelitian ini. Dengan adanya komunikasi antara fotografer dan model fotonya menjadi hal penting, guna 
mengurangi kesalahpahaman dan hal-hal yang akan merugikan keduanya. Hasil foto yang baik adalah foto yang mengandung etika, bukan hanya yang akan menguntungkan salah satunya saja, begitu pula untuk sang fotografer. Berdasarkan latar belakang di atas, maka peneliti akan melakukan penelitian tentang komunikasi fotografer dengan foto model mengenai intreraksinya dalam proses pembuatan karya foto dan dikaitkan dengan nilai etika dan moral dalam masyarakat.

Penelitian ini juga dilatarbelakangi oleh alasan belum adanya aturan yang mengatur tentang kode etik fotografer komersial. Disinilah letak keunikan penelitian yang akan dilakukan peneliti. Berdasarkan referensi yang diperoleh peneliti, belum ada penelitian sejenis yang meneliti tentang komunikasi verbal fotografer dan model dalam proses pembuatan karya fotonya. Berdasarkan latar belakang di atas, peneliti tertarik untuk mengangkat komunikasi verbal yang terjadi antara fotografer dan model dalam proses pemotretan.

\section{TINJAUAN PUSTAKA}

\section{Komunikasi Verbal}

Simbol, bahasa, atau pesan verbal adalah semua jenis simbol yang menggunakan satu kata atau lebih. Bahasa dapat juga dianggap sebagai sistem kode verbal (Mulyana, 2005). Bahasa dapat didefinisikan sebagai seperangkat simbol, dengan aturan untuk mengkombinasikan simbol-simbol tersebut, yang digunakan dan dipahami suatu komunitas.

Rakhmat (1994), mendefinisikan bahasa secara fungsional dan formal. Secara fungsional, bahasa diartikan sebagai alat yang dimiliki bersama untuk mengungkapkan gagasan. Ia menekankan dimiliki bersama, karena bahasa hanya dapat dipahami bila ada kesepakatan di antara anggota-anggota kelompok sosial untuk menggunakannya. Secara formal, bahasa diartikan sebagai semua kalimat yang terbayangkan, yang dapat dibuat menurut peraturan tata bahasa. Setiap bahasa mempunyai peraturan bagaimana kata-kata harus disusun dan dirangkaikan supaya memberi arti.

Menurut Larry L. Barker (Mulyana, 2005), bahasa mempunyai tiga fungsi: penamaan (naming atau labeling), interaksi, dan transmisi informasi.

1. Penamaan atau penjulukan merujuk pada usaha mengidentifikasikan objek, tindakan, atau orang dengan menyebut namanya sehingga dapat dirujuk dalam komunikasi.

2. Fungsi interaksi menekankan berbagi gagasan dan emosi, yang dapat mengundang simpati dan pengertian atau kemarahan dan kebingungan.

3. Melalui bahasa, informasi dapat disampaikan kepada orang lain, inilah yang disebut fungsi transmisi dari bahasa. Keistimewaan bahasa sebagai fungsi transmisi informasi yang lintaswaktu, dengan menghubungkan masa lalu, masa kini, dan masa depan, memungkinkan kesinambungan budaya dan tradisi kita.

Book (1980), mengemukakan agar komunikasi kita berhasil, setidaknya bahasa harus memenuhi tiga fungsi, yaitu:

1. Mengenal dunia di sekitar kita. Melalui bahasa kita mempelajari apa saja yang menarik minat kita, mulai dari sejarah suatu bangsa yang hidup pada masa lalu sampai pada kemajuan teknologi saat ini.

2. Berhubungan dengan orang lain. Bahasa memungkinkan kita bergaul dengan orang lain untuk kesenangan kita, dan atau mempengaruhi mereka untuk mencapai tujuan kita. Melalui bahasa kita dapat mengendalikan lingkungan kita, termasuk orang-orang di sekitar kita.

3. Untuk menciptakan koherensi dalam kehidupan kita. Bahasa memungkinkan kita untuk lebih teratur, saling memahami mengenal diri kita, 
kepercayaan-kepercayaan kita, dan tujuan-tujuan kita.

Book (1980), juga mengemukakan mengenai perbedaan bahasa yang dapat menimbulkan kesulitan lebih jauh daripada sekedar kekeliruan penerjemahan. Kita sering sulit menerjemahkan sebuah kata ke bahasa lain, karena tidak ada padanannya dalam bahasa lain itu, meskipun kita bisa mengira-ngira artinya. Bahkan ketika kita mampu menerjemahkan satu bahasa ke bahasa lain dengan kecermatan yang harfiah, maknanya yang dalam sering hilang karena makna tersebut berakar dalam budaya bahasa tersebut. Karena itu, kata-kata seperti Allah, salat, zakat, saum, dan haji sulit diterjemahkan ke dalam bahasa apa pun, termasuk Inggris.

Kelemahan dalam penguasaan tata bahasa, struktur, dan kosa kata (termasuk idiom, slang, dan jargon khusus) sering menghasilkan terjemahan yang membingungkan, menggelikan, dan terkadang bertentangan dengan apa yang dimaksudkan tulisan aslinya. Seperti Restroom berarti "kamar kecil", bukan "ruang istirahat"; dragonfly berarti "capung”, bukan "naga terbang". Sejumlah bahasa dalam bahasa Indonesia berasal dari bahasa Ingggris, namun dalam bahasa Indonesia mengalami perluasan makna. Misalnya kata family dalam bahasa Inggris berarti "keluarga" yang maknanya biasanya merujuk pada keluarga inti yang terdiri dari orang tua dan anak. Namun begitu dialihkan ke dalam bahasa Indonesia menjadi famili, arti kata tersebut mencakup juga kerabat atau saudara jauh, bukan sekedar keluarga langsung.

Berdasarkan asumsi bahwa bahasa adalah cermin suatu alam pikiran, dapat dimengerti bila istilah-istilah yang berkaitan dengan teknologi canggih dari negara asing seperti komputer, misalnya: drive, monitor, keyboard, mouse, file, dan printer, tetap dibiarkan dalam bahasa aslinya, karena sulit dicarikan padanannya, dan kalaupun ada padanannya, terkesan ganjil.

Sebaliknya, frase atau kalimat dalam bahasa Indonesia tidak bisa diterjemahkan begitu saja, secara kata per kata, ke dalam bahasa Inggris dan kesalahan dalam bahasa Inggris juga bisa timbul bila kita tidak menguasai tata bahasa (grammar) atau mengucapkan katakata secara salah.

Komunukasi verbal ternyata tidak semudah yang kita bayangkan. Simbol atau pesan verbal adalah semua jenis simbol yang menggunakan satu kata atau lebih. Hampir semua rangsangan bicara yang kita sadari termasuk ke dalam kategori pesan verbal disengaja, yaitu usaha-usaha yang dilakukan secara sadar untuk berhubungan dengan orang lain secara lisan.

Suatu sistem kode verbal disebut bahasa. Bahasa dapat didefinisikan sebagai seperangkat simbol, dengan aturan untuk mengkombinasikan simbol-simbol tersebut, yang digunakan dan dipahami suatu komunitas.

Jadi, bahasa verbal adalah sarana utama untuk menyatakan pikiran, perasaan, dan maksud kita. Bahasa verbal juga menggunakan kata-kata yang merepresentasikan berbagai aspek realitas individual kita. Dan konsekuensinya, katakata adalah abstraksi realitas kita yang tidak mampu menimbulkan reaksi yang merupakan totalitas objek atau konsep yang diwakili kata-kata itu.

\section{Fotografer dalam Ilmu Komunikasi}

Profesi atau pekerjaan apapun memerlukan pendalaman secara utuh, sehingga memancing dan merangsang pemikiran untuk men-set back, apakah profesi yang kita tekuni baik itu mahasiswa seperti layaknya peneliti ini, pegawai negeri, swasta, polisi, TNI, pedagang, supir, loper koran, guru, dosen, pemulung dan lain-lain, sudahkah kita resapi layaknya pakaian yang melekat dalam tubuh kita? Tentu saja jawabannya ada 
yang "ya, belum tentu, atau bahkan tidak sama sekali".

Sebagai salah satu profesi yang peneliti ambil yaitu, fotografer. Dikenal sebagai profesi yang bekerja di balik foto untuk mengabadiakan setiap momen yang terjadi di lingkungan kita. Walaupun setiap orang bisa menghasilkan foto menggunakan kameranya. Akan tetapi kebanyakan orang akan lebih percaya memberikan tanggung jawab mengabadikan momen hidupnya kepada seorang fotografer.

Baik tidaknya sebuah foto bisa kita lihat dari salah satu sudut pandang, yaitu tersampainya pesan yang dimaksud oleh fotografer. Seorang fotografer menghasilkan sebuah karyanya melalui sebuah foto, kemudian dinilai baik dari segi pesan yang disampaikan. Sebagai contoh, ketika fotografer mengabadikan momen sedih melalui kamera dan menghasilkan sebuah foto, selanjutnya kita bisa merasakan kesedihan dari gambar tersebut maka foto itu dinilai baik. Kita bisa menangkap maksud dan pesan dari fotografer tentang suasana sedih objek foto melalui foto yang dihasilkannya.

Foto yang baikpun tidak lepas dari konsep, ide dan sikap baik dari seorang fotografer. Terlepas dari persiapan fotografi penunjang dan peralatan fotografi, sikap baik seorang fotografer sangatlah penting. Setiap foto yang baik itu harus ada suatu proses sikap berfotografi yang baik dan tepat pada si fotografernya. Mungkin terdengar sederhana sekali. Tapi makin direnungi, fakta ini makin terasa kuat. Seseorang tidak mungkin menghasilkan foto yang baik, yang berkesan, apalagi yang berwatak bila tidak dilandasi sikap mental yang tepat.

$$
\text { Dalam rangka menghasilkan }
$$
sebuah mahakarya yang disebut foto, fotografer perlu melakukan eksplorasi terhadap karya seperti apa yang akan dia buat, melalui ide dan konsep sang fotografer, sikap bagaimana yang akan ia berikan terhadap karyanya tadi, sehingga pesan yang dimaksudkan bisa tersampaikan kepada orang lain yang melihat fotonya. Foto tadi dihasilkan melalui proses aktifitas fotografi, dimulai lahirnya sebuah konsep atau ide, buah hasil dari pemikiran, pengalaman, serta teknik yang dimiliki fotografer tersebut.

Menggunakan kamera serta peralatan lainnya yang menunjang, aktifitas memotret dalam hal ini fotografi bisa dilakukan. Dengan melihat berbagai hasil karya fotografer di sekitar kita, ada yang menyampaikan pesan dengan gambar hasil karyanya secara langsung, persuasif, sugertif, bahkan ada yang menyampaikan tanda tanya bagi publiknya. Tentu saja ini dipengaruhi oleh konsep dasar, art director, strata sosial publik bahkan fotografernya sendiri. Hingga akhirnya konsep diri yang didalamnya terdapat pengetahuan, pengharapan, serta nilai yang menjadi aspeknya terbentuknya mental berfotografi bagi seorang fotografer.

Fotografer atau juru foto (photographer) adalah:

"Orang-orang yang membuat gambar dengan cara menangkap cahaya dari subyek gambar dengan kamera maupun peralatan fotografi lainnya, dan umumnya memikirkan seni dan teknik untuk menghasilkan foto yang lebih bagus serta berusaha mengembangkan ilmunya. Banyak fotografer yang menggunakan kamera dan alatnya sebagai pekerjaan untuk mencari penghasilan." (KBBI, 2000)

Fotografi sering disebut sebagai aktivitas ekspresi diri seniman foto. Telah hadir lebih dari 1,5 abad yang lalu, dan telah menjadi sebuah inovasi tiada henti sejalan dengan perkembangan teknologi dan ilmu pengetahuan yang mendukungnya.

Fotografi berasal dari bahasa yunani, terdiri dari dua kata: photos berarti cahaya, dan graphos artinya melukis, menggambar. Secara harfiah Fotografi (photography) mengandung arti melukis atau menggambar dengan cahaya. Seni atau proses penghasilan gambar dengan cahaya pada film atau permukaan yang dipekakan. 
Fotografi merupakan aktivitas dimulai terbentuknya konsep atau ide foto, kemudian aktifitas memotret itu sendiri hingga hasil karya fotonya, menjadi fenomena yang dewasa ini hadir di manamana (omnipresence) bahkan di setiap elemen kehidupan masyarakat yang memasuki era informasi.

\section{Teori Interaksi Simbolik}

Esensi dari interaksi simbolik menekankan pada suatu aktivitas yang merupakan ciri khas manusia, yakni komunikasi atau pertukaran simbol yang diberi makna (Mulyana, 2003: 68). Banyak ahli di belakang perspektif ini yang mengatakan bahwa individu sebagai manusia merupakan hal yang paling penting. Mereka mengatakan bahwa individu adalah objek yang bisa secara langsung ditelaah dan dianalisis melalui interaksinya dengan individu yang lain. Menurut Larossa dan Reitzes (1993) interaksi simbolik pada intinya menjelaskan tentang kerangka referensi untuk memahami bagaimana manusia, bersama dengan orang lain, menciptakan dunia simbolik dan bagaimana cara dunia membentuk perilaku manusia. Interaksi simbolik ada karena ide-ide dasar dalam membentuk makna yang berasal dari pikiran manusia (Mind) mengenai diri (Self), dan hubungannya di tengah interaksi sosial, dan tujuan akhir untuk memediasi, serta menginterpretasi makna di tengah masyarakat (Society) dimana individu tersebut menetap. Mind, Self and Society merupakan judul buku yang menjadi rujukan utama teori interaksi simbolik, merefleksikan tiga konsep utama dari teori. Definisi singkat dari ke tiga ide dasar dari interaksi simbolik, yaitu:

1. Pikiran (Mind)

Pikiran adalah kemampuan untuk menggunakan simbol yang mempunyai makna sosial yang sama, dimana tiap individu harus mengembangkan pikiran mereka melalui interaksi dengan individu lain
(West dan Turner, 2008 : 102). Simbol yang bermakna adalah tindakan verbal berupa bahasa yang merupakan mekanisme utama interaksi manusia. Penggunaan bahasa atau isyarat simbolik oleh manusia dalam interaksi sosial mereka pada gilirannya memunculkan pikiran (mind) yang memungkinkannya menginternalisasi masyarakat. Jadi menurut Mead, pikiran mensyaratkan adanya masyarakat; dengan kata lain masyarakat harus lebih dulu ada sebelum adanya pikiran (Mulyana, 2003 : 84). Dengan demikian pikiran adalah bagian integral dari dari proses sosial, bukan sebaliknya proses sosial adalah produk pikiran.

Menurut Mead, lewat berfikir yang terutama ditandai degan kesadaran,manusia mampu mencegah tindakannya sendiri untuk sementara, menunda reaksinya terhadap suatu stimulus (Mulyana, 2003 : 86). Manusia juga mampu mengambil suatu stimulus diantara sekian banyak stimulus alih-alih bereaksi terhadap stimulus yang pertama dan yang paling kuat. Manusia pun mampu pula memilih suatu tindakan di antara berbagai tindakan yang direncanakan atau dibayangkan.

2. Diri (Self)

Diri adalah kemampuan untuk merefleksikan diri sendiri dari sudut pandang atau pendapat orang lain. Disini diri tidak dapat dilihat dari dalam diri seseorang melalui introspeksi diri. Bagi Mead, diri hanya bisa berkembang melalui kemampuan pengambilan peran, yaitu membayangkan diri dari pandangan orang lain (West dan Turner, 2007 : 103). Konsep melihat diri dari pandangan orang lain sebenarnya sebuah konsep yang pernah disampaikan oleh Charles Cooley pada 1912. Konsepnya adalah the looking glass self yaitu kemampuan melihat diri melalui pantulan dari pandangan 
orang lain. Cooley meyakini bahwa ada tida prinsip perkembangan sehubungan dengan the looking glass self, yaitu (1) membayangkan penampilan kita di hadapan orang lain, (2) membayangkan penilaian mereka terhadap penampilan kita, dan (3) merasa sakit hati atau bangga karena perasaan diri.

3. Masyarakat (Society) adalah jejaring hubungan sosial yang diciptakan, dibangun, dan dikonstruksikan oleh tiap individu ditengah masyarakat, dan tiap individu tersebut terlibat dalam perilaku yang mereka pilih secara aktif dan sukarela, yang pada akhirnya mengantarkan manusia dalam proses pengambilan peran di tengah masyarakatnya. Oleh karena itu masyarakat terdiri dari individuindividu yang terbagi kedalam dua bagian masyarakat yang mempengaruhi pikiran dan diri. Masyarakat yang pertama disebut Mead sebagai particular others yang berisikan individu yang bermakna bagi individu yang bersangkutan seperti anggota keluarga, teman dan rekan kerja, sedangkan masyarakat yang kedua adalah generalized others yang merujuk pada kelompok sosial dan budayanya secara keseluruhan. Generalized others menyediakan informasi tentang peranan, peraturan dan sikap yang digunakan bersama oleh komunitas, sedangkan particular others memberikan perasaan diterima dalam masyarakat dan penerimaan diri. Generalized others seringkali membantu mengatasi konflik yang terjadi dalam particular others.

\section{METODE PENELITIAN}

Metode penelitian yang digunakan peneliti dalam penelitian mengenai etika fotografer dalam menghasilkan karya foto adalah pendekatan kualitatif dengan studi interaksi simbolik. \begin{tabular}{crr}
\multicolumn{2}{c}{ Interaksi simbolik menurut } \\
perspektif interaksional,
\end{tabular} merupakan salah satu perspektif yang ada dalam studi komunikasi, yang barangkali paling bersifat "humanis" (Ardianto, 2007: 40). Di mana, perspektif ini sangat menonjolkan keangungan dan maha karya nilai individu di atas pengaruh nilai-nilai yang ada selama ini. Perspektif ini menganggap setiap individu di dalam dirinya memiliki esensi kebudayaan, berinteraksi di tengah sosial masyarakatnya, dan menghasilkan makna "buah pikiran" yang disepakati secara kolektif. Pada akhirnya, dapat dikatakan bahwa setiap bentuk interaksi sosial yang dilakukan oleh setiap individu, akan mempertimbangkan sisi individu tersebut, inilah salah satu ciri dari perspektif interaksional yang beraliran interaksionisme simbolik.

Teori interaksi simbolik menekankan pada hubungan antara simbol dan interaksi, serta inti dari pandangan pendekatan ini adalah individu (Ardianto, 2007). Banyak ahli di belakang perspektif ini yang mengatakan bahwa individu merupakan hal yang paling penting dalam konsep sosiologi. Mereka mengatakan bahwa individu adalah objek yang bisa secara langsung ditelaah dan dianalisis melalui interaksinya dengan individu yang lain.

(1993) dalam West-Turner (2008:96), interaksi simbolik pada intinya menjelaskan tentang kerangka referensi untuk memahami bagaimana manusia, bersama dengan orang lain, menciptakan dunia simbolik dan bagaimana cara dunia membentuk perilaku manusia. Interaksi simbolik ada karena ide-ide dasar dalam membentuk makna yang berasal dari pikiran manusia (Mind) mengenai diri (Self), dan hubungannya di tengah interaksi sosial, dan tujuan bertujuan akhir untuk memediasi, serta menginterpretasi makna di tengah masyarakat (Society) dimana individu tersebut menetap. Seperti yang dicatat oleh Douglas (1970) dalam 
Ardianto (2007: 136), Makna itu berasal dari interaksi, dan tidak ada cara lain untuk membentuk makna, selain dengan membangun hubungan dengan individu lain melalui interaksi.

Dadi Ahmadi (2008) dalam artikelnya juga menjelaskan tentang konsep interaksi dalam teori interaksi simbolik, manusia pada hakikatnya adalah mahluk yang berinteraksi. Bahkan, interaksi itu tidak hanya ekslusif antarmanusia, melainkan inklusif dengan seluruh mikrokosmos, termasuk interaksi manusia dengan seluruh alam ciptaan. Singkatnya, manusia selalu mengadakan interaksi. Setiap interaksi mutlak membutukan sarana tertentu. Sarana menjadi medium simbolisasi dari apa yang dimaksudkan dalam sebuah interakasi.

\section{Pendekatan dan Jenis Penelitian}

Penelitian kualitatif secara luas menggunakan pendekatan interprentif dan kritis pada masalah-masalah sosial.Penelitian kualitatif lebih memfokuskan dirinya pada makna subjektif, pendefinisian, metafora, dan deskripsi pada kasus-kasus yang spesifik (Neuman: 2000, 329). Mulyana (2005: 147-148) menyatakan bahwa penelitian kualitatif dalam ilmu komunikasi sebagai "perspektif subjektif" memiliki ciri sebagai berikut:

1) Sifat realitas: Realitas (komunikasi), bersifat ganda, rumit, semu, dinamis (mudah berubah), dikontruksi dan holistik : Kebenaran realitas bersifat relatif.

2) Sifat manusia (komunikator atau peserta komunikasi): Aktor (komunikator) bersifat aktif, kreatif dan memilki kemauan bebas; perilaku (komunikasi) secara internal dikendalikan oleh individu.

3) Sifat hubungan dalam dan mengenai realitas (komunikasi): semua entitas secara simultan saling mempengaruhi, sehingga peneliti tak mungkin membedakan sebab dari akibat.
4) Hubungan antar peneliti dan subjek penelitian: Setarap, empati, akrab, interaktif, timbal balik, saling mempengaruhi dan berjangka lama.

5) Tujuan penelitian: Menangani hal-hal bersifat khusus, bukan hanya perilaku terbuka, tetapi juga proses yang tak terucapkan, dengan sampel kecil atau purposive, memahami peristiwa yang punya makna historis, menekankan perbedaan individu, mengembangkan hipotesis (teori) yang terikat oleh konteks dan waktu; membuat penilaian etis atau estetis atas fenomena (komunikasi) spesifik.

6) Metode penelitian: Deskriptif (wawancara tak berstruktur atau mendalam, pengalaman berperan serta, analisis dokumen, studi kasus, studi histori; penafsiran sangat ditekankan alih-alih pengamatan objektif.

7) Analisis bersifat induktif; berkesinambungan sejak awal hingga akhir; mencari model, pola atau tema.

8) Kriteria kualitas penelitian: otentitas, yakni sejauh mana temuan penelitian mencerminkan penghayatan subjek yang diteliti (komunikator)

9) Peran nilai: Nilai, etika dan pilihan moral peneliti melekat dalam proses penelitian (pemilihan masalah penelitian, tujuan penelitian, paradigma, teori dan metode atau teknik analisis yang digunakan).

\section{Penentuan Data dan Sumber Data}

Data yang ada dalam penelitian kualitatif bersifat empiris, terdiri dari dokumentasi ragam peristiwa, rekaman setiap ucapan, kata dan gestures dari objek kajian, tingkah laku yang spesifik, dokumen-dokumen tertulis serta berbagai imaji visual yang ada dalam sebuah fenomena sosial (Neuman, 2000:328). Untuk mendapatkan hasil analisis yang mendalam, maka diperlukan data dari setiap tahapan penelitian.Data yang diperlukan berasal dari data primer dan data sekunder. 
Data primer diperoleh dari pihakpihak terkait langsung dengan penelitian yang terdiri dari :

1) Hasil pengamatan atau observasi terhadap perilaku informan pada penelitian tentang interaksi fotografer dengan foto model mengenai etika komunikasi fotografer dalam proses pembuatan karya fotonya

2) Hasil wawancara langsung secara mendalam dari informan penelitian tentang interaksi fotografer dengan foto model mengenai etika komunikasi fotografer dalam proses pembuatan karya fotonya

3) Data sekunder dapat mendukung ketajaman analisis penelitian. Data sekunder diperoleh dari rujukan khusus yang terdiri dari:

4) Literatur. Orientasi melalui bacaan yakni dengan menelaah literaturliteratur yang berisi teori-teori, kerangka pikir, serta brosur-brosur yang berhubungan dengan topik yang diteliti, yaitu yang berhubungan dengan etika fotografer.

5) Studi dokumentasi, hal ini untuk mendapatkan data-data sekunder yang digunakan untuk menunjang penelitian yang akan dilakukan.

Dalam penelitian yang dilakukan, yang dijadikan sumber data adalah pihak dari pakar/ahli dalam bidang fotografi, fotografer sendiri, sebagai narasumber kunci dan nara sumber lainnya yang terkait dalam hal "etika". Dalam penentuan sumber data berikutnya diperoleh dari petunjuk nara sumber awal dan seterusnya, hingga sampai pada titik batas perolehan informasi (data) terkait dengan masalah yang diteliti telah mencapai titik jenuh (Mulyana, 2005).

\section{Teknik Pengumpulan Data}

Teknik pengumpulan data dalam penelitian kualitatif adalah dengan melakukan observasi, wawancara mendalam, dan studi dokumentasi.

1) Observasi
Observasi yang dilakukan dalam penelitian ini adalah pengamatan. Pengamatan dilakukan dengan cara nonparticipant observation, terhadap objek yang diteliti yaitu proses interaksi fotografer dan model yang berkaitan dengan etika atau norma etis dan moral.

2) Wawancara Mendalam

Wawancara mendalam (depth interview) yang dilakukan peneliti dalam penelitian dimaksudkan untuk mengetahui pandangan, kejadian, kegiatan, pendapat, perasaan dari nara sumber (subjek matter expert). Wawancara yang dilakukan yaitu untuk mengetahui mengenai etika fotografer yang dilakukan, media komunikasi yang digunakan, sistem nilai yang disampaikan kepada para model dan asisten atau calon model serta informasi lainnya. Penggunaan teknik ini menurut Creswell (1998:120) sangat penting bagi penelitian kualitatif, terutama untuk melengkapi data dan upaya memperoleh data yang akurat dan sumber data yang tepat.

3) Studi Literatur

Studi literatur yang dilakukan dalam penelitian ini adalah dengan menelusuri data-data dari beberapa sumber yang terkait dengan penelitian ini. Misalnya, literatur tentang fotografer, model, dan interaksi simbolik dari buku-buku Ilmu Komunikasi maupun dari penelitian terdahulu yang serupa.

\section{Informan Penelitian}

Dalam penelitian ini, informan yang dipilih peneliti adalah fotografer dan model mulai dari amatir yang sekedar hoby dan yang profesional. Teknik dalam penelitian kualitatif ini adalah purposive sample (teknik sampel bertujuan) dimana sample diambil dengan melalui pertimbangan tertentu sesuai dengan tujuan penelitian.

1. Dewi Hasari, Model Profesional

2. Dea Nabila, Model Profesional

3. Rizki Septiani, Model Freelance 
4. Budi Ipoenk, Fotografer Profesional

5. Anjar Sapta, Fotografer Profesional

\section{HASIL DAN PEMBAHASAN}

\section{Hasil}

Dalam bagian ini, peneliti akan menjelaskan hasil penelitian yang dilakukan mengenai interaksi antara fotografer dan model ketika proses pembuatan karya foto. Interaksi antara fotografer dan model akan sangat beragam, tergantung dari individu masing-masing. Foto yang baikpun tidak lepas dari konsep, ide dan sikap baik dari seorang fotografer. Terlepas dari persiapan fotografi penunjang dan peralatan fotografi, sikap baik seorang fotografer sangatlah penting. Setiap foto yang baik itu harus ada suatu proses sikap berfotografi yang baik dan tepat pada fotografernya. Mungkin terdengar sederhana sekali. Tapi makin direnungi, fakta ini makin terasa kuat. Seseorang tidak mungkin menghasilkan foto yang baik, yang berkesan, apalagi yang berkarakter bila tidak dilandasi sikap mental yang tepat.

Dalam proses menghasilkan sebuah karya yang disebut foto, fotografer perlu melakukan eksplorasi terhadap karya seperti apa yang akan dia buat, melalui ide dan konsep sang fotografer, sikap bagaimana yang akan ia berikan terhadap karyanya tadi, sehingga pesan yang dimaksudkan bisa tersampaikan kepada orang lain yang melihat fotonya. Foto tadi dihasilkan melalui proses aktifitas fotografi, dimulai lahirnya sebuah konsep atau ide, buah hasil dari pemikiran, pengalaman, serta teknik yang dimiliki fotografer tersebut.

Sebagai makhluk sosial, sebagai fotografer, kita tidak luput dari hubungan manusia. Bila kita hobi foto model, maka kita akan berhubungan langsung dengan manusia sebagai modelnya. Kalaupun hobi kita foto pemandangan, tetap saja kita harus berhubungan dengan orang lain di lokasi untuk mendapatkan informasi atau bantuan. Maka dari itu masalah interaksi, adalah masalah yang penting. Namun topik ini biasanya jarang di bahas, fotografer biasanya lebih tertarik membahas soal kamera, lensa, pencahayaan dan lain lain.

Maksud dari interaksi dalam penelitian ini adalah bagaimana cara kita berhubungan antar manusia, antara fotografer dan model, antara fotografer dan asisten, atau fotografer dan masyarakat lokal. Memiliki interaksi yang baik, fotografer tentunya diuntungkan dengan mendapatkan banyak kemudahan dalam membuat karyanya, karena orang-orang di sekitar kita pun akan lebih senang membantu kita.

Secara ideal, memiliki interaksi yang baik berarti fotografer dalam menyampaikan ide dan konsep foto yang ia inginkan kepada modelnya adalah dengan bersikap rendah hati, hormat terhadap orang yang menjadi subjek fotonya. Menerapkan tata krama etika moral yang baik dalam interaksinya dengan model, seorang fotografer selain mendapatkan hasil foto yang ia inginkan, ia juga akan mendapatkan rasa hormat dari modelnya.

Dalam sebuah sesi pemotretan idealnya interaksi yang terjadi antara fotografer dan model berlangsung sejak awal fotografer bertemu dan membicarakan konsep foto yang akan dilaksanakan. Dalam interaksi yang terjadi tersebut hendaknya fotografer dan modelnya merasa nyaman dengan interaksi yang terjadi sehingga interaksi yang terjadi berlangsung efektif. Setelah interaksi yang terjadi pada saat prapemotretan, interaksi terus berlangsung pada saat pemotretan, pada saat proses pemotretan berlangsung interaksi terus berlangsung, terutama saat fotografer mengarahkan modelnya. Interaksi tersebut juga idealnya berlangsung dengan baik sehingga kedua belah pihak baik fotografer dan model merasa nyaman dengan interaksi yang berlangsung, sehingga interaksinya berjalan efektif.

Sikap yang baik dari seorang fotografer lebih jarang ditemui peneliti dalam sesi-sesi pemotretan yang peneliti 
observasi. Dalam sesi fotografi yang lebih bersifat privat atau kalangan fotografer menyebutnya dengan sesi pemotretan KT (kategori terbatas) dimana fotografer terkesan memiliki kuasa yang penuh atas modelnya, sehingga interaksi yang terjadi menjadi tidak baik. Terkadang fotografer dengan berani menyentuh, memegang, memandangi dan berbicara seenaknya.

Terkadang dalam sesi pemotretan privat fotografer sering kali berusaha melanggar kesepakatannya dengan modelnya. Fotografer terkadang sering mengambil keuntungan dari modelnya, seperti pemilihan wadrobe dan konsep pemotretan yang tidak sesuai dengan kesepakatan awal dengan modelnya.

Berbeda dengan sesi pemotretan komersial, dimana dalam sesi tersebut segala sesuatunya jauh lebih tertata dan terencana dengan baik, dan juga lebih banyak pihak yang terlibat, sehingga interaksi fotografer terhadap modelnya menjadi lebih terbatas dan terawasi, karena bukan hanya fotografer dan model saja yang terlibat dalam sesi pemotretan tersebut ada pihak lain seperti: klien dari fotografer tersebut, make-up artist, hair stylist, bagian wadrobe dan masih banyak lagi pendukung lainnya. Pada sesi ini interaksi fotografer dan modelnya baik secara verbal dan nonverbal menjadi sangat terbatas, dan sangat terkesan interaksi yang terjadi hanya sebatas melaksanakan tugas profesionalisme masing-masing.

Dalam penelitian ini, peneliti menggunakan informan kunci dan informan pendukung. Adapun yang menjadi informan kunci adalah tiga orang model yang sengaja dipilih sesuai dengan kriteria penelitian, model yang bervariatif dari segi profesionalisme dan berpengalaman dalam dunia modeling. Untuk data pendukung, peneliti mewawancarai fotografer, dalam hal ini fotografer ternama yang sudah berpengalaman dalam dunia fotografi, khususnya yang memahami mengenai interaksi fotografer dan model dalam proses pembuatan karya foto.

\section{Pembahasan}

\section{Interaksi Verbal Fotografer dan Model}

Sebelum menceritakan tentang interaksi fotografer dan model selama proses pengambilan foto, maka disini peneliti menjelaskan terlebih dahulu tentang konsep dari fotografer dan model itu sendiri.

Hans-Carl Koch (1911) berkata, "Today only creative and technically perfect images will survive". Kutipannya ini memaparkan bahwa, fotograferfotografer yang memiliki kreatifitas dan teknik yang baik yang akan bertahan. Kreatifitas terbentuk dari pemikiran, ideide, cara pandang, keinginan, permintaan, minat yang ditata dengan nilai-nilai, pemahaman, serta moralitas sang fotografer yang terbentuk dari konsep diri sang fotografer itu sendiri.

Fotografi merupakan aktivitas dimulai terbentuknya konsep atau ide foto, kemudian aktifitas memotret itu sendiri hingga hasil karya fotonya, menjadi fenomena yang dewasa ini hadir di manamana (omnipresence) bahkan di setiap elemen kehidupan masyarakat yang memasuki era informasi.

Memotret adalah proses kreatifitas yang tidak hanya sekedar membidik obyek yang akan kita rekam dan kemudian menekan tombol shutter pada kamera. Dalam menciptakan sebuah karya foto kita harus mempunyai ide (konsep) yang matang agar tidak mengalami kesulitan dilapangan dan yang tidak kalah pentingnya adalah memahami tentang komposisi, ketajaman dan pencahayaan (teknis).

Informan pertama, Dewi, sebagai model profesional, dalam pengalamannya selama tiga tahun menekuni profesi model yang juga cita-citanya semenjak kecil untuk menjadi seorang yang terkenal dan disukai banyak orang. Awal karirnya sebagai model dimulai sejak masa awal 
perkuliahannya ia mengikuti kontes pemilihan model catwalk dan menjadi pemenang, mulai dari itu lah Dewi mulai mengikuti berbagai lomba model dan kemudian mulai mendapatkan tawaran pemotretan lalu memutuskan untuk terus menekuni profesinya.

Perlakuan yang dewi terima saat menjalankan tawaran pemotretan, awalnya ia merasa risih dengan perlakuan fotografer terhadap dirinya, seperti yang Dewi ungkapkan kepada peneliti:

"Pas pertama kali jadi model sih, awalnya gue ngerasa risih ama fotografer-fotografer nakal yang suka godain pas lagi proses pemotretan. Kaget banget, kok mereka pada berani gitu sih, pegang-pegang gue, ngarahin gaya gue sambil ngerayu-rayu gitu, tapi gue coba ikutin aja prosesnya. Soalnya pas liat hasil fotonya, gue juga seneng, ternyata foto-foto gue bagus juga, hehe.. gue jadi sangat pede kalau berpose di depan kamera. Terus jadi semakin tertantang untuk dipotret dengan gaya-gaya baru lainnya."

Perkataan-perkataan godaan dan rayuan-rayuan yang di katakan oleh fotografer kepada modelnya terkadang menjurus kearah pelecehan dan merendahkan model, namun perlakuan fotografer yang sebenarnya tidak menyenangkan tertutupi oleh hasil foto yang cukup memuaskan. Godaan-godaan dan rayuan-rayuan dilakukan fotografer terhadap modelnya secara terus menerus, sehingga perbuatan yang tidak menyenangkan tersebut sudah dia anggap sebagai hal yang wajar dan dianggap biasa bagi fotografer dalam memperlakukan modelnya, seperti yang Dewi ungkapkan:

"Tapi yang ngeselinnya sih, mereka ya suka gitu habis manis sepah dibuang, gue kadang suka gampang jealous juga kalo fotografer gue motret model lain dengan interaksinya sama kayak ke gue, mesra sambil ngerayu-rayu gitu. Suka kesel juga, bete, pengen marah. Gue jadi sering sakit hati sama fotografer, akhirnya gue punya persepsi, pokoknya semua fotografer itu sama brengseknya. Kalau soal interaksi gue sama fotografer sih ya kayak gitu, gue jadi terbiasa sama tingkah laku mereka. "

Dengan perlakuan yang sama yang dilakukan fotografer terhadap modelmodelnya, maka muncul sebuah anggapan bahwa perilaku tersebut menjadi sebuah kewajaran yang terjadi dalam interaksi antara fotografer dan model.

Interaksi verbal yang terjadi dalam salah satu sesi pemotretan privat yang Dewi alami, fotografer berusaha merayu Dewi untuk melakukan sebuah sesi foto yang berbeda dengan perjanjian awal yang mereka tawarkan. Ucapan-ucapan verbal yang fotografer ucapkan sangat terkesan merendahkan dan melecehkan model. Dan dalam situasi tersebut Dewi tidak memiliki pilihan selain menuruti apa yang fotografernya minta, meskipun permintaan itu dilakukan dengan nada-nada yang merendahkan dan melecehkan, Dewi berasumsi jika dia tidak mengikuti apa yang fotografer itu inginkan maka ia tidak akan mendapatkan fee yang fotogarfer tersebut janjikan, ia merasa akan mengalami kerugian karena hal tersebut.

$$
\text { Informan kedua, Dea Nabila }
$$
memiliki cerita yang berbeda tentang interaksinya dengan para fotografer. Seperti telah dijelaskan sebelumnya, Dea cenderung sangat selektif dan tidak pernah berurusan langsung dengan para fotografer. "Alhamdulilah sejauh ini, aku selalu mendapatkan pelayanan yang baik dari fotografer. Maksudnya ya, interaksi aku sebagai model pun berjalan sesuai dengan konteksnya, aku model, dia fotografer. Tapi kalau untuk interaksinya sih, masih dalam batas wajar kok. Selama 1,5 tahun kan aku bekerja sebagai model freelance, pas lagi masa-masanya belajar jadi model, hehee... Tapi alhamdulilah kok, interaksi yang aku alamin sama fotografer ya sebatas format wajar saja. Aku dipotret, mereka ngarahin gaya. Gak pernah ada fotografer yang berani macem-macem juga sama aku. Misalnya, interaksi wajar itu, sejauh ini ya kalo aku kecapean trus susah ngikutin gaya yang diarahin sama fotografer, biasanya mereka lebih sabar. 
Istirahat dulu sebentar, terus kalau baju aku agak sedikit terbuka, ada bagian make up atau manajer yang bantuin aku benerin baju. Jadi, gak pernah ngelibatin langsung fotografernya. Kalau aku keringetan, biasanya bagian make up juga yang bantuin aku ngelapin keringat. Alhamdulilah, gak pernah ada kejadian macem-macem kok."

Perlakuan fotografer terhadap model yang dialami oleh Dea berbeda dengan apa yang dialami Dewi, Dea lebih terlindungi karena Dea berada dibawah naungan sebuah kontrak yang jelas dan sebuah agensi model yang profesional, sehingga semua pemotretan sangat teratur dan terawasi oleh agensi tersebut dan pemotretan tersebut berjalan dalam koridor profesionalisme. Namun Dea juga tidak memungkiri jika ada upaya fotografer untuk melakukan perlakuan yang tidak profesional dari seorang fotografer, namun bagimana model menyikapinya, jika model membiarkannya, maka fotografer akan semakin berani terhadapnya, begitu sebaliknya, jika model besikap tegas maka fotografer akan segan terhadap modelnya.

Dalam sesi pemotretan profesional yang dialami Dea, fotografer hanya berinteraksi seperlunya dengan modelnya. Fotografer baru berinteraksi dengan modelnya hanya pada saat pemotretan. Pada saat persiapan sesi pemotretan, fotografer dan asistennya sibuk menyiapkan setup sesi pemotretan, dan model akan disibukan oleh make-up artis dan bagian wadrobe yang disiapkan untuk pemotretan. Praktis interaksi fotografer dan model hanya terjadi saat proses memotret, dan perintah-perintah yang fotografer berikan disampaikan secara baik dan sopan. Dalam sesi ini semua dilakukan dengan tertata dan terancana baik, namun situasi pemotretan profesional seperti ini terkesan menjadi sangat kaku, dimana proses pemotretan yang terjadi hanya sebatas menghasilkan sebuah foto dan setelah itu selesai, tiada kesan dinamik semua terkesan kaku.
Dea juga sangat selektif memilih tawaran pemotretan pada dirinya, seperti yang dia ungkapkan kepada peneliti:

"Pada intinya sih, kalau menurut aku, setiap model itu harus memiliki prinsip. Dia bekerja sebagai model yang profesional, seharusnya bersikap tegas dan punya prinsip, bagaimana seharusnya berinteraksi dengan para fotografer. Kalau aku sih, emang dulu juga suka banyak yang pedekate, pake modus nawarin kontrak kerja pemotretan segala, tapi aku sih selalu bersikap tegas. Terus kalau ada yang nawarin job pemotretan dengan pakaian yang minim, sexy, dan terbuka, aku suka langsung nolak. Lebih baik kehilangan job tersebut, daripada harus ngambil resiko. Tentunya masih ada rezeki lain dari Allah buat aku, bukan hanya job yang harus menggunakan pakaian sexi tersebut. Aku sih mikirnya gitu. Jadi, pada intinya sih, seperti itulah seharusnya seorang model yang profesional. Bersikap tegas dan memiliki prinsip, sehingga tidak akan terjadi interaksi fotografer dan model di luar batas yang telah ditentukan. Ya, kecuali mungkin, mereka memang samasama mau. Model yang seperti itu jugalah sebenarnya yang merusak citra model yang sesungguhnya. Kadang-kadang aku suka kesel juga kalo denger banyak cerita gak enak soal model dengan fotografer. Tapi, seperti sudah aku jelasin, kembali lagi pada model tersebut, model itu harus bersikap tegas dan memiliki prinsip."

Dea memiliki prinsip yang kuat dalam profesinya menjadi seorang model, Dea tidak segan-segan untuk menghentikan sesi pemotretan jika ia merasa dirugikan, ia tidak memikirkan kerugian yang ia alami jika menghentikan sesi foto yang ia anggap sudah tidak sesuai dengan perjanjian awal yang ia terima.

Informan ketiga, model yang memiliki hobi "berpose di depan kamera ini" menuturkan kisahnya ketika berinteraksi dengan para fotografer. Iqy Avril, begitulah panggilan akrabnya. Iqy sempat mengalami aksi tipu dari fotografer 
yang mengaku sebagai fotografer profesional.

Iqy menjadi sorang model berawal dari hobi berpose dan bergaya di depan kamera, lalu kemudian beberapa teman dekatnya mengajaknya untuk melakukan sesi pemotretan, dan terus berlanjut sampai sekarang. Interaksi fotografer dan model yang dialami Iqy cenderung lebih terkendali, karena Iqy sangat selektif dalam memilih fotografer yang memotret dirinya, ia hanya memilih fotografer yang sudah benar-benar ia kenal. Pengalaman buruk interaksi dengan fotografer yang ia alami adalah saat ia mendapatkan broadcast message dari sekelompok fotografer yang sedang mencari model untuk penerbitan sebuah majalah, fee dari sesi pemotretan itu sangat menggiurkan sekali sehingga ada banyak model yang terpancing untuk mengikutinya, setelah sesi pemotretan yang panjang sekelompok fotografer itu menghilang tanpa memberikan konpensasi yang merekan janjikan pada model-modelnya.

Janji-janji yang diberikan fotografer pada Iqy hanya merupakan iming-iming saja, karena pada kenyataannya semua yang dijanjikan tidak terlaksana. Walaupun interaksi awal terjalin dengan baik namun pada akhirnya.

\section{PENUTUP}

\section{Simpulan}

Interaksi verbal fotografer dengan foto model dalam proses pembuatan karya foto terjadi secara bervariasi, bergantung dari fotografer dan model menentukan perannya. Interaksi verbal fotografer dan model akan berjalan harmonis, selaras, dan seimbang sesuai dengan nilai etika dan moral, jika kedua pihak tersebut saling menghargai profesi masing-masing dan utamanya tetap menjunjung tinggi unsur etika dalam berprofesi. Harmonisasi interaksi verbal akan terganggu, bahkan rusak dan berjalan di luar nilai etika dan moral jika salah satu pihak, baik fotografer atau model mulai memancing melakukan interaksi verbal yang dinilai melanggar aturan nilai dan moral sedangkan pihak lainnya membiarkan atau bahkan menanggapinya dengan hal yang sama.

\section{Saran}

1. Dibentuknya sebuah aturan etika yang jelas dan disepakati bersama tentang pola interaksi yang terjadi antara fotografer dan modelnya, yang dapat berlaku umum sehingga baik profesi fotografer maupun model terhindar dari citra buruk yang sekarang terlanjur berkembang karena pengaruh oknumoknum, baik oknum fotografer maupun oknum model yang cara kerjanya menyimpang dari nilai etika dan kaidah moral yang berlaku. Sehingga fotografer dan model dapat lebih mudah mengetahui apa yang boleh dan yang tidak mereka lakukan dalam dunia fotografi.

2. Dibentuknya sebuah organisasi formal yang mewadahi para fotografer amatir dan model amatir sehingga dapat menjadi wadah pendidikan dan akan lebih mudah menjalankan fungsi pengawasan. Agar fotografer dan model mendapatkan pendidikan dan pengetahuan yang lebih dalam mengenai dunia yang akan mereka geluti.

\section{DAFTAR PUSTAKA}

Ahmadi, Dadi. 2008. Interaksi Simbolik, Sebuah Pendekatan Penelitian dan Teori. Jurnal Mediator No.9/Vol 2/Des 2008.

Ardianto, Elvinaro dan Bambang Q-Anees. 2007. Filsafat Ilmu Komunikasi. Bandung: Simbiosa Rekatama Media.

Creswell. 2006. Qualitative Inquiry and Research Design : Study Case. Sage Publications, Incorporated. 
Book, Cassandra L. 1980. Human Communication: Principles, Contexts, and Skills. St. Martin's Press New York

Mulyana, Deddy. 2005.Ilmu Komunikasi:

Suatu Pengantar. Bandung:

Remaja Rosdakarya.

Mulyana, Deddy. 2003. Metode Penelitian

Komunikasi. Bandung: Remaja

Rosdakarya. . Jurnal Mediator No.9/Vol 2/Des 2008. Fakultas Ilmu Komunikasi Universitas Islam Bandung.

La Rossa, R dan Reitzes, D. C. 1993. Symbolic Interaction and Family Studies. Canada : Thousand Oaks.

Kamus Besar Bahasa Indonesia. 2000. Jakarta: Pusat Bahasa Depdiknas.

Neuman, W. Lawrence. 2000. Social Research Methods. Qualitative and Quantitative Approach, 4th ed. Boston: Allyn and Bacon.
Rakhmat, Jalaluddin. 1994. Metode Penelitian Komunikasi. Bandung: PT. Remaja Rosdakarya.

West, Richard dan Lynn H. Turner. 2008. Pengantar teori Komunikasi: Analisis dan Aplikasi. Buku 1 edisi ke-3. Terjemahan. Maria Natalia

\section{Artikel Elektronik}

http://www.fotografinet.co.id, diakses pada 10 Februari 2017

http://jocette.com/2012/03/28/the-modelalliance-survey-finds-that-30-of-modelshave-been-sexually-harassed-and-50exposed-to-cocaine/, diakses pada 30 Januari 2017 http://www.cetitamu.com/cerita-gayahidup/Fashion/Artikel/ModelAlliance-Membeberkan-Fakta-DalamIndustri-Mo., diakses pada 30 Januari 2017 